\title{
Understanding of Geography Teacher towards Geopark as Learning Resources
}

\author{
Igna Juli Triana, Mamat Ruhimat* \\ Universitas Pendidikan Indonesia \\ Bandung, Indonesia \\ mamatruhimat@upi.edu
}

\begin{abstract}
Learning practices, including learning of Geography is expected in visual form. Geography, has a lot of learning resources, whether it's physical or even socio-cultural. The aim of this research is to reveal teacher knowledge towards Geopark as a learning resources of geography. Research was conducted with distributing some questions about geopark as learning resources. The subject of this research was geography teachers of High School in Sukabumi District, West Java. Research result shows that the level of teacher knowledge towards geopark as learning resources are still low. This has an impact on the low level of teachers' use of Geopark as a learning resource. This research is expected to encourage government and education researchers to immediately develop the teaching materials based on geopark condition.
\end{abstract}

\section{Keywords - geography teacher; geopark; learning resources}

\section{INTRODUCTION}

The Geopark concept was conceived by UNESCO (United Nations Educational, Scientific and Cultural Organization). Geopark then developed along with a non-governmental organization that formed to protect geological heritage in European countries named EGN (Europe Geopark Network). After that, UNESCO facilitate and forming an organization that could gather more member countries, so that Global and Geopark Network (GGN) was formed in 2004. Geopark officially accepted as UNESCO program as the new icon of Geoheritage utilization based on sustainable development and tourism of Indonesia. Global Geopark is an area that has geological heritage with international value, that heritage is used as a development asset of its society that sustainable basically of conservation, education and economy creative. Conservation can also contribute to the economic development of the community [1]. Geopark is a nationally protected area containing a number of geological heritage sites of particular importance, rarity or aesthetic appeal. These Earth heritage sites are part of an integrated concept of protection, education and sustainable development. A Geopark achieves its goals through a three-pronged approach: Conservation, education and geotourism [2]. Furthermore, the UNESCO Global Geoparks Network has established geotourism in the geopark region as a strategic tourism sector and impacts on nature conservation [3]. While developing geotourism, the establishment of geoparks can generate new job opportunities, new economic activities and additional sources of income, especially in rural regions [4]. Geopark were integrate three types of natural diversity as geodiversity, biodiversity and cultural diversity. In addition to its geology, a geopark should also make use of sites of archaeological, ecological, historical or cultural significance as these are often linked to the underlying geology [5].

The development of Geopark itself based on the pillar of conservation, education, and growth of local economic value aspects. Those pillars being a holder of Geopark development goals, which is to honor earth heritage, and the objective of its development was to make their society prosperous. These objective and target then became slogan of Geopark that was socialized around the world [6]. One of highlight that would be submitted to be Global and Geopark Network of 2017 is Geopark Ciletuh-Palabuhan Ratu. Ciletuh has a unique geological diversity and it's the oldest in West Java. This area was a result of collides of two different tectonic plates, that is: Eurasian Plate (continental plate) that composed of granit (acid), and Indo-Australian Plate that composed of basalt (alkali) that resulting the deepest oceanic trench, a place which pelagic sediment rocks, metamorphic rock, and alkali to ultraalkali igneous rock penetrated, was very interesting to learned.

Geodiversity in geopark needs to be taught to students considering it is one of the priceless natural wealth [7]. Various rocks that has been mentioned above mixed and raised on the surface named melange (mixed rock) and it belongs to the oldest rocks group (Pre Tersier) that exposed on Java Island surface, with its age around $120-65$ million years old [8]. Other uniqueness is the whole of outcrop was in a large valley that resembling amphitheater with horseshoe shape according to Bulletin of Scientific Contribution, opened to the direction of Indian Ocean that occurred by tectonic process in the form of ruins. In addition, some waterfalls, sea caves, and small islands that rich in geological meaning is also decorate this area. Geopark Ciletuh has uniqueness that not exists in other Geopark in Indonesia. Geopark Ciletuh features an outstanding geological heritage site that has international value in the form of tectonic fossils of continental plate and oceanic plate collisions that occurred at Karst age, also the spectacular amphitheater morphology. Those thing makes Geopark Ciletuh officially being national Geopark at December 22, 2015. A Geopark organizes activities and provides logistic support to communicate geoscientific knowledge and environmental concepts to the public. This is accomplished through protected and interpreted geosites, museums, information centers, trails, 
guided tours, school class excursions, popular literature, maps, educational materials and displays, seminars and so on. A Geopark also fosters scientific research and cooperation with universities and research institutes, stimulating the dialogue between the geosciences and local populations. In Indonesia, many have used geopark as a learning resource by many education institutions.

Geopark is very suitable to use as geography learning resources, because it was complete, not only has physical element but also the socio-cultural components. Schools and teachers are expected to maximize utilization of geopark as much as possible. Schools has to use a lot of learning resources that useful to gain students motivation in learning [9]. The aim of this research is to reveal geography teacher knowledge towards geopark as learning resources.

Learning resources is all of information whether in the form of data, or people who can support learning processes. Learning resources is a power that could be utilized for learning and teaching purposes, partly or entirely [10]. Definition of learning resources is very wide, because basically the experiment itself was wide enough, that is all of the things that can be experienced and considered as learning resources as long as it brings us to an experience and causes learning [11]. Learning resource covers everything that used to learning purposes, that is all the thing that exists in school in the past, present, and future [12]. Learning resources is a resources that can be used in the process of learning and teaching and give the easiness to student and teacher. Learning resources is not only exists in learning and teaching processes in school but it also obtained from our experience as long as it brings us to a learning to a better direction. Types of learning resources can be categorized as six that is place or environment, things, human, materials, books, and events. Learning resources consists of four category that is things, scientific paper, human, and environment [13]. Role of teacher in choosing learning resources were strongly influence the process of learning, whether indoor or outdoor learning. Besides, the interaction between teachers and students can develop teachers' ideas on the development of teaching materials [14]. Learning plan or learning program has contained required learning resources in learning activities. Teachers were expected to analyze the needs of learning resources based on material and objectives of learning. In addition, teacher were expected to have knowledge and ability to identify various learning resources, choosing and determining the appropriate learning resources, also using learning resources in learning activities. The existence of learning resources in school is still apprehensive and needs development, whether its type or diversity or even quantity. Learning resources that has been understood by school principal, teachers, and students is only around textbooks, speakers, and learning media. Whereas speakers were limited to teachers, and other resources is not much or almost never involve in learning in school. Meanwhile, students really want variety of learning resources for their learning activities [15]. In geography learning activity, most of teacher did the process of teaching and learning only to transferring their experience and still a lot of them using lecture method which gave monotone impression because geography is a subject that learn about various natural phenomenon, so that it has many learning resources and one of them is the environment around us. The first theories of experiential learning arose in the midnineteenth century as attempts to move away from traditional formal education, where teachers simply presented students with abstract concepts, and toward an immersive method of instruction. Students would "learn by doing," applying knowledge to experience in order to develop skills or new ways of thinking. Environment is every things (things, conditions, situations) that exist around living things that influence (characteristics, developments, distributions) that living thing itself. Until now, some of Geography Teacher around Sukabumi District still seeing Geopark Ciletuh as only a tourism location. Environment as a learning resources related to human interaction with society life, such as social organization, custom and habits, livelihood, culture, education, population, government structure, religion and value system. Environment can be used as learning resource of geography, because it has a lot of phenomenon to be a learning resources, so that the purpose of this environment utilization to make students more active in learning, expand their insight and knowledge's, and can be a citizen who taking care and protect also preserve their environment [13]. Utilization of environment as learning resources can make students easier to absorb learning materials, knowing about their environment condition more, implementing knowledge and skill they have learn, also familiar with their environment. In addition, environment utilization as learning resources is to make students more active, make them easier to absorp knowledge they learned, more familiar with their environment, and being a citizen who taking care and protect also preserve their environment.

\section{METHOD}

This research method that used is survey method. Results of data collecting from sample will be generalized or all of population. Population of this research was all of geography teacher in SMA (High School) Negeri in Sukabumi District. Total of geography teacher in Sukabumi District is 47 people (Education Department of Sukabumi District, 2017). This research using simple random sampling with the amount of 10 people as research sample. Data collecting technique is in the form of observation and questionnaire distribution. Validity of data was tested by credibility, transferability, dependability, and confirmability.

\section{RESULT}

No matter how great curriculum is, teacher still holding decisive role. Role of teacher is irreplaceable. In accordance with concept and factual, the existence of geopark will enrich learning resources, especially Geography. Any actor of education, primarily Geography Teacher is supposed to have an intact knowledge about geopark. A number of questions that related with Geopark existence and its utilization as learning resource were distributed to the teachers. The data result about teacher knowledge to geopark can be seen on figure 1 . 


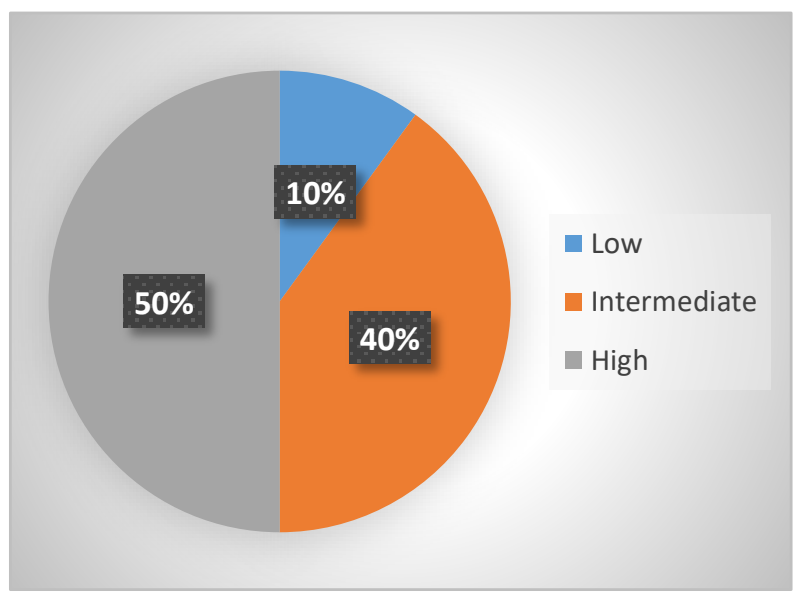

Fig. 1. Level of teacher knowledge about geopark.

Based on figure 1, the knowledge of High School geography teacher at low level were $40 \%$, intermediate $50 \%$ and high is only around $10 \%$. Majority of geography teacher has been recognize Geopark Ciletuh, but only as a tourism asset. As for characteristics of geodiversity, biodiversity and culture diversity, there were only a few who has been knew. Most of teachers getting the information through mass media as their knowledge resource about Geopark. This low level of teachers knowledge about geopark is a reason why they do not utilize geopark as a learning resources in school and more interesting thing is some teacher who has utilizing geopark as learning resources turn out to have a low level of knowledge about geopark. According to the above research results, variety of serious effort to make geography teachers understand geopark is required. Function and role of geopark was undoubtful anymore conceptually, but in other side knowledge of geography teacher about it is still low.

Environment, for geography learning resources, is to utilizing the around environment, will also developing sense of belonging to that environment. The affection to environment will not happen immediately, but it needs a process, and one of them are to make the around environment as geography learning resources. Nationalism will not suddenly going down from heaven, but it needs process too, one of them are the introduction to environment as geography learning media. Geopark in this research was located in Ciletuh, West Java, it is so strange if not being recognized, especially not being utilized as learning resources. Media, originally known simply as an aid in learning activities that serve to provide as a visual experience to students, increase learning motivation, clarify, and simplify the complex and abstract concepts become more simple, concrete and easy to understand [16].

One day geography teacher carry their students directly visiting geopark to observe the formation, process and utilization by society and government. Field trip is a learning and teaching method where students with teacher guidance are invited to visit certain places in the purpose of learning. Field trip has some benefit, that is : a. Field trip has modern teaching principles that utilizing real environment in studying, b. Make things that learned in school more relevant with reality and society needs, c. This kind of studying will be a stimulus for students creativity, d. Information of learning materials will be more wide and actual [17]. More benefit of field trip are: a. Students can observe diversity of realities from near, $b$. Students can comprehend new experiences through trying to involve in an activity. c. Students can answer the problems or statements through seeing, trying, and proving directly, d. Students can obtain the information through interview or listening to lecture which was given during learning activity that going on, e. Students can learn something intensively and comprehensive. In addition, other benefits of field trip are: a Students obtained learning experience that was not acquired from school, so that opportunity could develop special talent or skill of students, b. Students can see various activity in the outside environment and it makes student experience deeper and wider, c. Students can obtain variety of knowledge and the integrated and cohesive experiences through object which they observe directly. But in the other side, field trip definitely has some weakness, such as: a. The necessary facilities and its cost are difficult to be provided by students or schools, b. Urgently requires careful preparation or planning c. Requires coordination with teacher so overlapping will not happen during field trip, d. In field trip, recreation often more prioritized so learning substance being slighted e. That is kind of difficult to organize a lot of students in the trip and hard to direct them into activity that being a problem. Those weakness should be reduced, or even be vanished by teacher strategies to implementing outdoor learning. Preparation of student worksheets, observation manual, questionnaire, maps and using practical equipment can be the efforts to cover outdoor weaknesses.

\section{DISCUSSION}

Geopark has enormous potential to be developed as a learning resource. Geodiversity, biodiversity, and culture diversity is a geopark component that must be mastered by a teacher. Mastery of teachers to geopark conditions will affect the development of teaching materials. Spatial aspects (social aspects and physical aspects) are important information in the development of teaching materials about geopark lessons [18] In other words, teachers who master the characteristics of learning resources will be able to develop quality teaching materials. Teachers also have to master the knowledge of curriculum that apply today. The teaching materials should be relevant to the curriculum used. This will affect the effectiveness of teaching materials to improve the quality of education in a country. If possible, teachers need to develop electronic-based teaching materials to make it easier for students to access them [19].

In the previous section it has been mentioned that teachers have a low level of knowledge on Geopark Ciletuh Palabuhan ratu. This low level of knowledge has an impact on the low use of geopark as a learning resource. Geography teacher need to get some training, especially in utilization of environment as learning media. Training pattern for teacher have to be directed to the creativity development more than adminstratively training [20]. Socialization, courses can be done, but it is expected to more involving teacher directly to utilizing geopark as a resources and media of learning. Pictures, photos can be a visualization of learning material. In a time geography teacher 
practices directly to a geopark location under qualified instructor. Resources and media of learning will visualize materials that being learned. Ability to finding and using relevant resources, is one of the important component in teacher's pedagogical competency. Teachers also show motivation and responsibility on the improvement of their professional competencies [21].

In addition, the use of geopark as a learning resource must be supported by an informative student worksheet. The material presented by the teacher will not be accepted by the students entirely. This is due to the use of field trip study methods. Field trip method is done outside the classroom with unfavorable environmental conditions. Noise from people around is one factor that can disrupt the concentration of learners. Therefore, student worksheet can help learners to understand the lessons better.

The important role of government and universities is needed in solving this problem. The government plays a role in imposing regulation system that can encourage teachers to master any information in the geopark region. While universities has a role to accelerate the mastery process of teachers to the material about geopark. Teachers need direction and training in developing Geopark-based teaching materials from experts in universities. It also serves as an anticipation of different concepts between one teacher and another teacher. If teachers are allowed to develop geopark-based teaching materials with their own, it is a risk of occurrence there will be many different concepts that impact on the confusion of students.

\section{CONCLUSION}

Most of high school geography teacher still have a low knowledge about geopark as a learning resource. It needs serious efforts to introducing geopark for teachers, especially geography teacher through some media and opportunities, formal or non-formal. Knowledge of geopark were obtained mainly from media mass information. The teachers' majority said that geopark was being positioned only as tourism object. Learning activities, especially that related directly with the environment utilization as a learning resources were has not discovered by teachers. Samples and simulation of geopark utilization as geography learning resources needs to be practiced and cultivated to the teachers. This research was a beginning stage, it needs further research in the future primarily that related with geopark utilization as a learning resources and might be about the affect to its learning process and results.

\section{REFERENCES}

[1] Halim, S. A., and Ishak, N. A. "Examining Community Engagement in Heritage Conservation through Geopark Experiences from The Asia Pacific Region”, Kajian Malaysia,vol. 35, pp. 11-38, 2017.

[2] UNESCO, International Guidelines Global Geopark, Unesco, 2015
[3] Farsani, N. T., Coelho, C. O. and Costa, C. M. "Analysis of Network Activities in Geoparks as Geotourism Destinations", International Journal Tourism Research, vol.16, pp.1-10, 2014.

[4] Farsani, N. T., Coelho, C. and Costa, C. "Geotourism and geoparks as novel strategies for socio-economic development in rural areas" International Journal Tourism Research, 2011, vol.13, pp. 68-81.

[5] Ramsay, T. Forest Fawr Geopark - "a UNESCO Global Geopark distinguished by its geological, industrial and cultural heritage", Proceedings of the Geologists' Association, vol. 128, Issue 3, June 2017 , pp. 500-509.

[6] Rachmat. H, "Peran Pemerintah Daerah Untuk Mendukung Geopark Nasional Rinjani Menjadi Rinjani Unesco Global Geopark (Role of Local Government To Support National Geopark Rinjani Becomes Rinjani UNESCO Global Geopark)." Seminar Nasional Ke - III, Fakultas Teknik Geologi Universitas Padjadjaran , 1-9.

[7] Crofts, R. "Promoting geodiversity: learning lessons from biodiversity. Proceedings of the Geologists' Association." Vol. 125, Issue 3, July 2014, pp. 263-266.

[8] Schiller, D.M., Garrard, R.A., and Prasetyo, L. "Eocene Submarine Fan Sedimentation in Southwest Java", Proceedingss IPA ke 20:Jakarta, 2011.

[9] Lisyana, I. "Pemanfaatan Lingkungan Setempat sebagai Sumber Pembelajaran oleh Guru Geografi di SMA Negeri se-Sukabumi Selatan (Local Environment Utilization as Learning Source by Geography Teacher in Public High School in South Sukabumi.)." Skripsi Sarjana Pendidikan pada Jurusan Pendidikan Geografi FPIPS UPI Bandung: (Unpublished)

[10] Rusman. Pembelajaran Jigsaw (Jigsaw Learning), Jakarta: Bumi Aksara 2008.

[11] Dale. E, Audio-Visual Method in Teaching, New York: Drydenn Press, 1954.

[12] Sudjana, Desain dan Analisis Eksperimen (Design and Analysis of Experimental), Bandung: Tarsito, 1989.

[13] Ningrum. E, Kompetensi Profesional Guru dalam Konteks Strategi Pembelajaran (Teacher Professional Competencies in the Context of Learning Strategies), Bandung : Buana Nusantara, 2009.

[14] Solem. M, Geography Education, Workforce Trends, Twenty-First-Century Skills, and Geographical Capabilities. In International Encyclopedia of Geography: People, the Earth, Environment and Technology (eds D. Richardson, N. Castree, M. F. Goodchild, A. Kobayashi, W. Liu and R. A. Marston), 2017.

[15] Agustina. D, Kompetensi Guru Dalam Pemanfaatan Sumber Belajar Geografi SMA Negeri (Teacher Competency in Geography Learning Resources Utilizing in Public High School). Jurnal Ilmiah Pendidikan Geografi , 71-81, 2014.

[16] Umar, Media Pendidikan: Peran dan Fungsinya dalam Pembelajaran (Learning Media: Role and Function in Learning), Jurnal Tarbawiyah, vol. 10, no. 2, Juli-Desember 2013

[17] Djamarah. S B, Strategi Belajar Mengajar (Teaching Strategy). Jakarta: Rineka Cipta, 2006.

[18] Riveraa, F. M., Ruiz, M. T., Guzmán, G., Ibarra, M. M., and Quintero, $\mathrm{R}$, A collaborative learning approach for geographic information retrieval based on social networks. Computers in Human Behavior, vol. 51, part B, October 2015, pp. 829-842.

[19] Gang. Y, The construction of multi-dimensional teaching environment: A qualitative study on the redesign of all-encompassing teaching materials 1, New Waves, vol.17, 2, pp. 1-11, 2014.

[20] Yani. A, Penundaan Implementasi Kurikulum 2013 di Indonesia: Perspektif Budaya dan Sosial Politik di Era Kabinet Jokowi-JK, dalam Sosio Humanika, Jurnal Pendidikan Sains Sosial dan Kemanusiaan, vol. 9 (1), Mei 2016, pp. 153- 172.

[21] Widodo. A, Riandi, and Muhammad N H, Dual Mode in-servis training as an alternative model for Teachers Professional in Indonesia, International Journal of Education, vol 5, no. 2, May 2011, pp. 175 185 . 